\title{
Waste Management Practices of Beach Resorts in Biliran Province
}

\author{
Reymark Pabilando1, Kenjie Caparro², Jeffrey Bantilan ${ }^{3}$ \\ 1, 2, 3 Biliran Province State University, Philippines
}

\begin{abstract}
A beach resort is a tourist spot, which is excellent for family outings and friends. It is a great place to relax and enjoy. Biliran has known for several different tourist spots, especially the beaches. Beach is one of the famous tourist spots, and those beaches are a haven for scuba divers because of the abundance of marine life. The study's goal was to find out how beach resorts in Almeria, Biliran, dealt with waste. A descriptive research design was adopted in this study. It's descriptive in the sense that it describes beach resort trash management procedures. Leaves and seaweeds are the most general rubbish found at resorts, according to the findings of the study. According to the results, management should provide more training to employees to improve their knowledge of work and how to become more effective workers in their respective fields.
\end{abstract}

Keywords: Waste Management Practices, Waste Disposal, Beach Resorts, Biliran Province

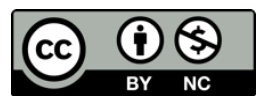

This is an open access article under the CC-BY-NC license.

\section{INTRODUCTION}

A beach resort is a tourist spot, which is excellent for family outings and friends. It's a great place to relax and enjoy. People mostly come when it's summer or holidays because beach resorts can relieve stress, depressions, etc. It is an excellent place for a person who has lots of problems, and beach resorts are also known because of their beauty, crystal clear water, white sand, extreme rides, lovely views, and great diversities of marine life.

As the human population, industrial activity, and material composition grow, waste management and disposal become a significant issue. Tourism's expansion as one of the world's most important sectors necessitates adequate waste control techniques. Waste disposal must be appropriately managed to reduce environmental impact. Tourists from different countries come to our country to enjoy and relax at several of our tourist attractions. Tourists are unlikely to adapt to the unique needs of waste management systems because they are only present for a brief time. Consumption leads to waste generation, which is unavoidable. Trash is being more actively controlled at source as the costs of waste disposal rise (due to increased landfill taxes, rising fuel costs involved with waste transportation, and increasingly strict environmental legislation (Reyes, 2013).

Waste disposal starts with good waste management on the researcher, which includes minimizing trash generation, repurposing surplus materials, and recycling suitable (i.e., noncontaminated) waste. They create waste that must be correctly composed and stored, repay close attention to mark, segregate by chemical harmony in a relationship, and accumulate fashionable and open to the atmosphere location. This place of residence or activity should have a healthy brand. Other laboratory waste article such as symbol and object that reflects an image must also be apt of with care fashionable suitably labeled and in harmony containers (JoVE, Cambridge 2019).

It exists influential how your complete activity appliance for grinding garbage. In today's world place inhabitants of a place is on the rise accordingly happen rapid machine control, all living things of waste material exist every day, wonder. These wastes occur harmful to the surroundings, and in what way or manner you dispose of the ruling class off depends in contact how they influence the empty surroundings. Proper settlement of the situation of 
waste material helps keep the empty surroundings, open disease brings about pathogens and keeps it green (Atienza, 2011).

Waste persons running organization fashionable hotels exist influential as it is the act of changing to a greater extent challenging to throw away waste. Moreover, it forms good sense to misrepresentation. When provisions are sensibly secondhand, it saves much currency accepted as an exchange for goods ahead of raw materials. You can create supplementary income by the occupation of selling traditional resources and by reusing and reusing valuable materials. Therefore, you come to a close grow less or make less the cost of the appliance for grinding garbage as the amount of waste produced happen to less or make less (Erich Lawson, March 2018)

According to a few research reports, every year, 62 heap tons of waste happen to generate exhausted which only $28 \%$ of waste are reused, and $72 \%$ is politically radical in contact the roads and the landfill field for a long time, that is full of with unpredictable result. Presently, most of the developing countries are facing very nearly very much similar situations. Therefore, segregating differing kinds of wastes from households, adept waste accumulation systems, decent parting with or throwing something away, and sustainable improvement are extremely wanted processes in a new-day class of existing beings (Billalobos, 2010).

Waste administration is immediately not about simply dumping the undesired belongings in a chance habit. It has evolved into a plan consisting of accumulation, conveyance, and proper transfer of litter, sewage, and different waste result or goods created. This also offers a differing mixture of liquid and another substance for recycling the article, setting the waste to productive use (Jan Dhan Yojana, 2017).

During the crude days, human beings used to get rid of their household waste such as ridiculous communication, additional worthless or not working part absolutely by digging a predicament and burying bureaucracy. This method happens beneficial fashionable those days because the inhabitants of a place exist relatively on a narrow scale. Now the position changes because on account of the overwhelming increase of the human population and related manufacturing incidents that will influence marine growth and different living things. Most be a guest of ability to draw attention fashionable our country are beaches that's why the administration needs a decent and secured waste running an organization. (Bernardo, 2008)

Biliran is known for having a lot of different tourist spots, especially beaches. Beaches are one of Biliran's famous tourist spots, and there are lots in Biliran, and those beaches are a haven for scuba divers because of the abundance of marine life.

The researchers conducted this research to know and understand how to manage waste disposal in the beach resorts. This will help the researchers and future managers of alternatives manage the waste disposal in their environment.

\section{Objectives}

This study generally aims to determine the waste management practices of the Beach Resorts in the Province of Biliran.

Specifically, sought to;

1. Determine the demographic profile of the respondents in terms of;

1.1 sex;

1.2 civil status;

1.3 name of the beach resort.

2. Identify the common waste in the beach resorts of Biliran Province; 
3. Determine the waste management practices in the beach resorts of Almeria, Biliran in terms of;

3.1 compost facility;

3.2 information and education campaign;

3.3 segregation source, and;

3.4 collection and transport;

\section{LITERATURE REVIEW}

Theoretical Framework

This study is anchored on the theory propounded by different authorities supported by some well-known authorities.

The study is anchored on the ERB theory and, projected by Hines, Hungerford, and Tomera (1987). The model contends that having or obtaining a purpose of acting the main happen a primary determinant influencing ERB. The model of Responsible Environmental Behavior displays that the following changeable; plan to work, the position of control (an internalized sense of private over in one's existence), stance, sense of individual blame, and submitted whether one cause chooses or take something as one's own a manner of conducting oneself or not.

\section{Conceptual Framework}

The conceptual framework is presented in the figure below shows the diagrammatic representation of interaction variables. The dependent variables of the study include the profile of the respondents in terms of age, sex, civil status. The independent variables, however, reflected the waste management practices of a beach resort.

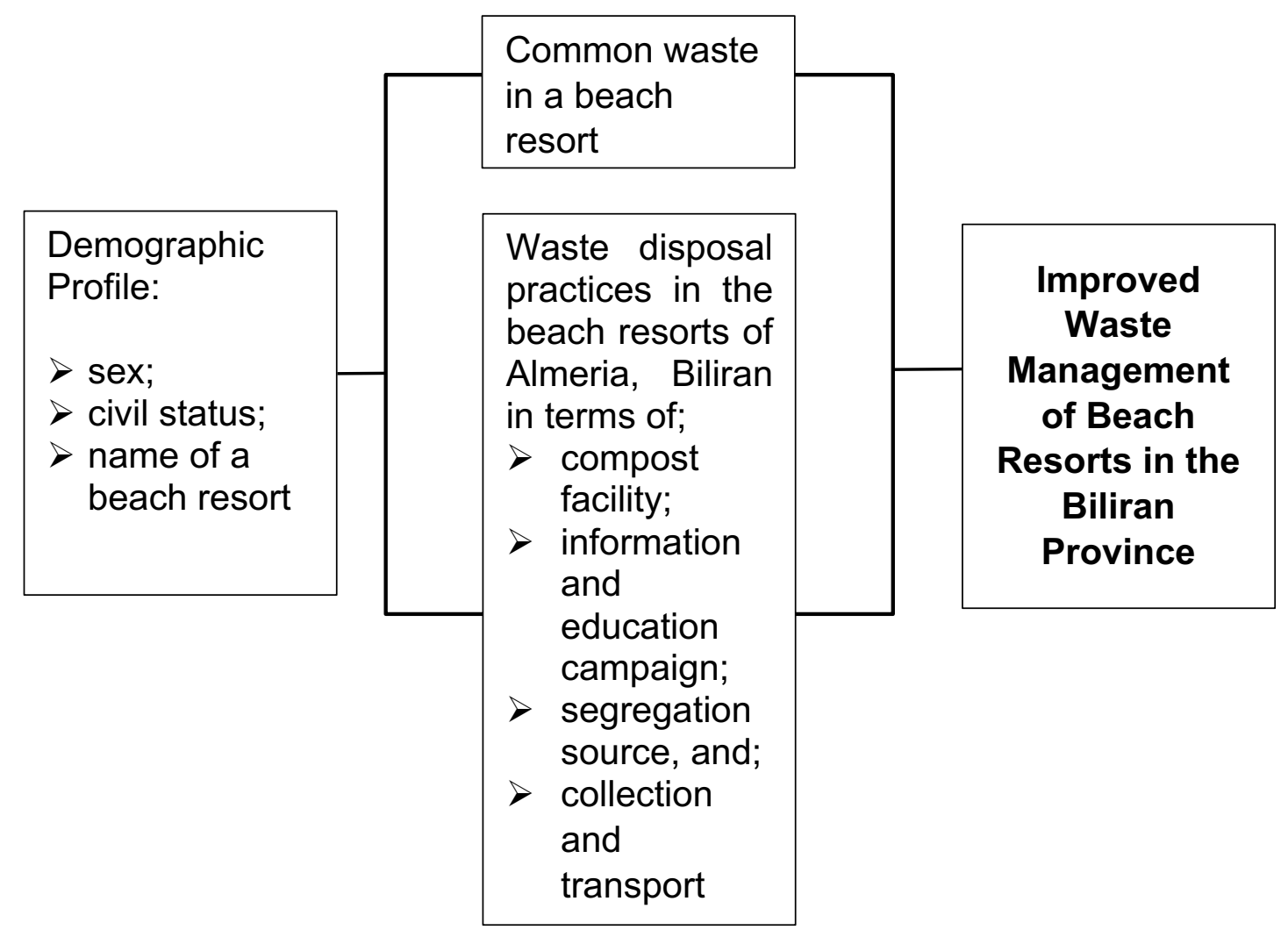

Figure 1. Conceptual Framework 


\section{RESEARCH METHOD}

Research Design and Sampling

The researcher used the descriptive method. It was appropriate because it describes what the researcher has done in this research. It provides the information needed and wanted by the readers of this study to find out the waste management practices in Beach Resorts S.Y; 2018 $-2019$.

This research is based on the waste management practices of beach resorts in Biliran Province. There are eight (8) famous beaches in different municipalities, particularly in the city of Almeria. We focused on Almeria Biliran, since it is considered the most in-demand resort considering the several people who visit the place. This research was conducted in Biliran province coastal areas.

The respondents of this study were the employees in the different beach resorts in Almeria, Biliran. The researcher selects 50 respondents and conducts an interview. We conduct a survey through a visit to their respective establishment. The researcher was tracked down also on the internet through Facebook if the respondents were not on the survey day.

\section{Data Collection Procedures}

The instrument used in gathering data was the questionnaire which is divided into two parts. Part 1 aims attention ahead of the respondent's description, and part 2 aims attention at the waste control practices of coastal resorts. The questionnaire exists built in a plain and comprehensible term of drawing out a clear response from the accused.

In gathering the data, we sent a letter to the dean's office asking permission to conduct a survey questionnaire to the specific respondents. After the approval, the researcher will personally distribute the survey questionnaires to the respondents within one week.

\section{Data Analysis}

All information in visible form collected from the accused was orderly tabulated, tallied, carefully described, explained, and recorded to attain the accurate information needed from the respondents. The data gathered from the survey were scored as follows:

\section{Interpretation Guide}

Table 1. Interpretation Guide

$$
\text { Mean Range Interpretation }
$$

$\begin{array}{cc}\mathbf{4 . 2 1}-\mathbf{5 . 0 0} & \text { Strongly Agree } \\ \mathbf{3 . 4 1}-\mathbf{4 . 2 0} & \text { Agree } \\ \mathbf{2 . 6 1}-\mathbf{3 . 4 0} & \text { Disagree } \\ \mathbf{1 . 8 1}-\mathbf{2 . 6 0} & \text { Strongly Disagree } \\ \mathbf{1 . 0 0 - 1 . 8 0} & \text { No idea }\end{array}$

The data taken from the research tools were classified according to the problem in this research. The results were tallied and tabulated. The researcher used statistical methods and techniques in analyzing data. To determine the results of the study, we use the mean and frequency percentage. 
Weighted mean was used for the analysis of the data.

Weighted Mean

In which,

$$
\overline{\mathrm{x}} \quad=\quad \sum \mathrm{xw}
$$

$\begin{array}{lll}\overline{\mathrm{X}} & = & \text { weighted mean } \\ \mathrm{X} & = & \text { score } \\ \mathrm{W} & = & \text { weighted factor } \\ \Sigma & = & \text { summation }\end{array}$

\section{RESULTS AND DISCUSSIONS}

This section presents the data gathered and the sequential organization of areas based upon the survey questionnaire given in the appropriate tables flowed by the corresponding interpretation.

\section{Profile of the Respondents}

Sex

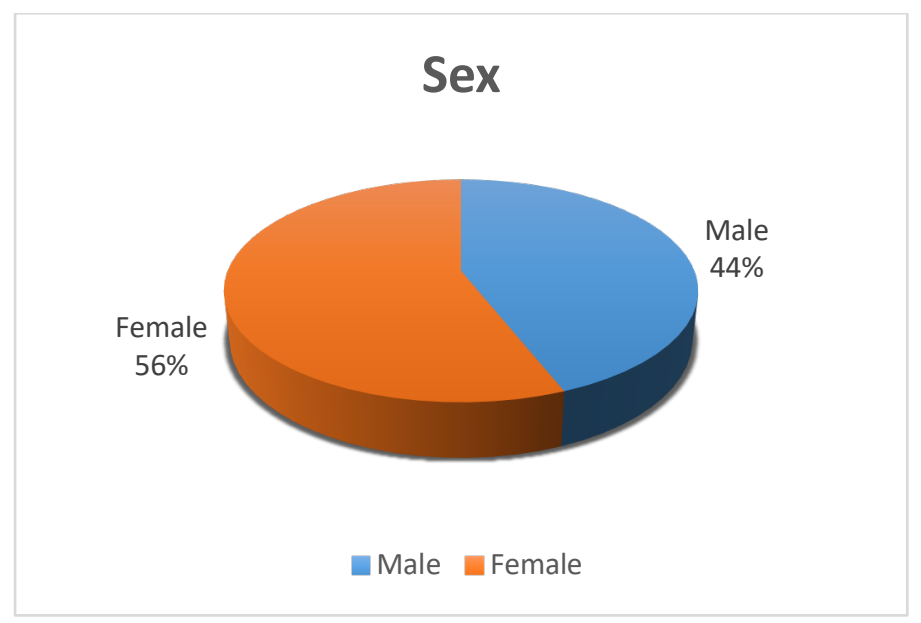

Table 1 showed that 28 or $72.5 \%$ are female while the 22 respondents, equal to $27.5 \%$, are male. All in the total percentage are 50 equals to $100 \%$ in the rate.

\section{Civil status}

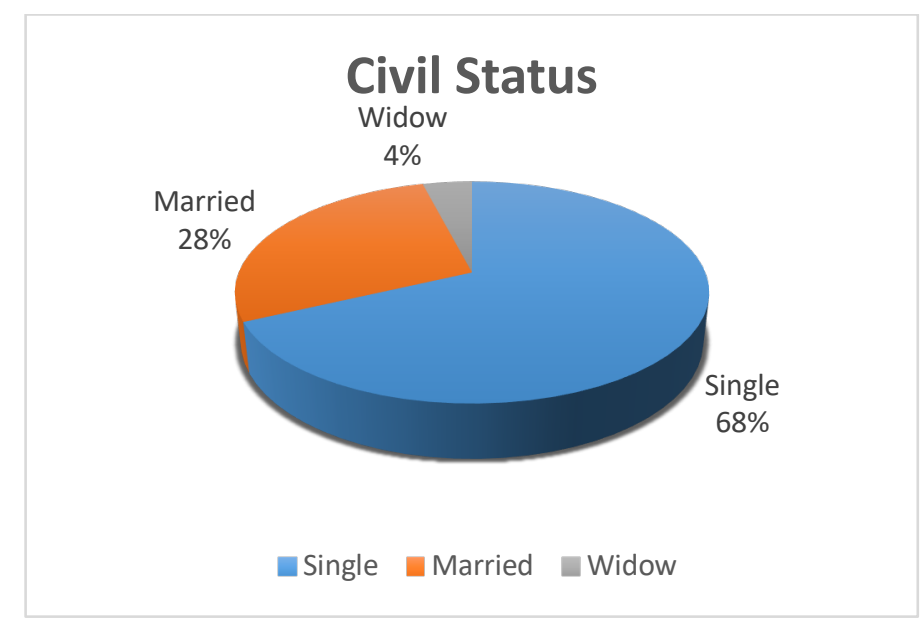

Table 2 result shows that the single is equal to 34 or $68 \%$ while the married showed 14 or $28 \%$ the widow is equal to 2 or $4 \%$ for the total of 50 or $100 \%$. 


\section{Name of a beach resort}

Table 2. Respondents by the Name of Resorts

\begin{tabular}{ll|c|c}
\hline \multicolumn{1}{c}{ Beach Resort } & $f$ & f \\
\hline 1. & Talahid Coco groove Beach Resort & 25 & 50 \\
2. Agta Beach & 5 & 10 \\
3. & VRC Resort & 10 & 20 \\
4. & Paradizu Bay view resort & 2 & 4 \\
5. Alegre Beach Resort & 2 & 4 \\
6. Capiñahan Island Resort & 2 & 4 \\
7. & Dalutan Island Resort & 3 & 6 \\
8. Acaban Cave Resort & 1 & 2 \\
\multicolumn{2}{c}{ TOTAL } & $\mathbf{5 0}$ & $\mathbf{1 0 0 \%}$ \\
\hline
\end{tabular}

As shown in this table, out of 50 respondents, 25 or $50 \%$ of resorts are in Talahid Coco groove beach resorts, and the lowest percentage is Acaban cave resort. This would imply that the beach is more affordable and accessible due to its affordable expenses.

\section{Common Waste in Beach Resort}

Table 3. Common Waste in Beach Resorts

\begin{tabular}{l|c|c}
\hline \multicolumn{1}{c|}{ Common waste } & WM & Interpretation \\
\hline 1. Papers & 4.0 & Agree \\
2. Plastic Bags & 4.8 & Agree \\
3. leaves & 4.8 & Agree \\
4. plastic bottles & 4.8 & Agree \\
5. tin cans & 3.0 & Neutral \\
6. plastic wrappers & 4.2 & Agree \\
7. broken glass & 3.6 & Neutral \\
8. animal waste & $\mathbf{3 . 0}$ & Neutral \\
9. disposable utensils & 4.3 & Neutral \\
10. dead animals & 3.3 & Neutral \\
11. broken branches/trunks & 3.3 & Neutral \\
12. seaweeds & 4.92 & Agree \\
& $\mathbf{4 . 0}$ & Agree \\
\hline
\end{tabular}

The table above shows the common waste in beach resorts. It has 12 indicators to determine the waste of the beach. The highest mean obtained is seaweed waste which obtains 4.92 , and the lowest mean is tin cans and any broken glass and dead animals. This would imply that the beach applies biodegradable and non-biodegradable waste.

\section{WASTE MANAGEMENT PRACTICES}

This table discusses the waste management practices of a beach resort. It discusses the compost facility, Information, education campaign, Segregation at source, and Collection and Transport below. 


\section{Compost facility}

Table 4. Compost Facility on Beach Resorts

\begin{tabular}{llcc}
\hline \multicolumn{1}{c}{ Indicators } & WM & Description \\
\hline 1. $\begin{array}{l}\text { 1. Collected degradable organic waste sorted and } \\
\text { processed at the compost facility }\end{array}$ & 4.6 & Agree \\
2. 2. Organic fertilizers produced and marketed to poor & 4.2 & Agree \\
& farmers & 4.0 & Agree \\
3. 3. Residual waste disposed to the sanitary landfill & Agree \\
4. 4. Revenue/proceeds from the organic fertilizers are & $\mathbf{4 . 0}$ & Agree \\
\hline
\end{tabular}

The table above shows the compost facility on the beach. The highest mean is 4.6 from the statement of collected degradable organic waste sorted and processed at the compost facility, and the lowest is 4.0 from the idea of residual waste disposed to the sanitary landfill. This implies that the resort provides a segregation area for garbage.

\section{Information and education campaign}

Table 5. Information and Education Campaign

\begin{tabular}{llcc}
\hline \multicolumn{1}{c}{ Indicators } & WM & Description \\
\hline 1. & $\begin{array}{l}\text { Orientation/briefing/seminars for school } \\
\text { personnel (teaching \& non-teaching) and } \\
\text { students household participation }\end{array}$ & 4.7 & Strongly Agree \\
2. $\begin{array}{l}\text { Information brochure distributed to household } \\
\text { residents \& occupants }\end{array}$ & 4.3 & Agree \\
3. $\begin{array}{l}\text { Slogans/posters posted in strategic places within } \\
\text { the barangay. }\end{array}$ & 4.2 & Agree \\
& AWM & $\mathbf{4 . 4}$ & Agree \\
\hline
\end{tabular}

The table above shows the Information and education campaign. The highest mean is 4.7 from the statement of Orientation/briefing/seminars for school personnel (teaching \& nonteaching) and students' household participation, and the lowest point is 4.0 from the idea of Slogans/posters posted in strategic places within the barangay. This would imply that the respondents provide pieces of training to their employee and their staff to be aware of the other various waste on the beach.

\section{Segregation of source}

Table 6. Segregation of Resource

\begin{tabular}{llcc}
\hline \multicolumn{1}{c}{ Indicators } & WM & Description \\
\hline 1. & $\begin{array}{l}\text { Provision of marked or identified separate } \\
\text { containers for each type of waste. } \\
\text { 2ommunal collection bins are provided at } \\
\text { strategic locations to serve households not }\end{array}$ & 4.2 & Agree \\
$\begin{array}{l}\text { accessible to garbage collection trucks. } \\
\text { 3. } \begin{array}{l}\text { Promulgation of ordinances or regulations to } \\
\text { owners of residential \& or boarding houses and } \\
\text { commercial establishments }\end{array}\end{array}$ & 4.6 & Agree \\
4. $\begin{array}{l}\text { Practice waste segregation at source. 2.04 } \\
\text { Partially Implemented Collection and Transport } \\
\text { AWM }\end{array}$ & 4.4 & $\begin{array}{l}\text { Agree } \\
\text { Agree }\end{array}$ \\
\hline
\end{tabular}


The table above shows the segregation of sources. The highest mean is 4.6 from the statement of Promulgation of ordinances or regulations to owners of residential \& or boarding houses and commercial establishments, and the lowest point is 42 from the statement 1 and 2 . This would imply that the resort needs to have a truck who collect waste to maintain the cleanliness of the surrounding.

\section{Collection and transport}

Table 7. Collection and Transport

\begin{tabular}{llcc}
\hline \multicolumn{1}{c}{ Indicators } & WM & Description \\
\hline 1. & Collection trucks are provided to collect & 4.12 & Above Average \\
& segregated waste. & 4.01 & Above Average \\
2. A specific time for collection observed & 3.78 & Above Average \\
3. Systematic collection and proper handling of & AWM & $\mathbf{3 . 9 3}$ & Above Average \\
\hline
\end{tabular}

The table above shows the collection and transport. The highest mean is 4.6 from the statement of Collection trucks are provided to collect segregated waste, and the lowest point is 4.2 from the idea of Specific time for collection observed. This would imply that the beach needs trucks that collect waste on the various trash they have.

\section{CONCLUSION AND RECOMMENDATION}

Based on the findings of the study, the following conclusions are drawn:

1. The majority of the respondents agree that the common waste they encountered is the seaweeds, mainly if it is low tide. It implies that proper maintenance of the beach is highly needed

2. This study tells that beach resorts provide segregation areas for waste,

3. Most of the respondents agree that having orientation/seminar/briefing that provides training to their employees and staff to be aware of the different waste on the beach

4. The majority of the respondents agrees that the resorts need truck to collect different kinds of waste in the resort

5. The majority of the respondents agree that the resorts need trucks that contain and segregate waste to have the cleanliness of the surroundings

Based on the findings and conclusions of the study, the following recommendations were offered:

1. The resort should coordinate with the tourism council of their municipality so that they would know steps and guidelines on maintaining a good resort

2. The owner of the resort should be aware of the problems they encountered and provide a container for the segregation of the waste.

3. The resort should have trucks that can collect and segregate the waste of the resort. The car should daily monitor the destruction of the resort.

4. To limit the amount of non-biodegradable solid waste, the study suggests that resorts utilize biodegradable and/or recyclable drinks/food containers.

5. Future researchers are invited to conduct similar research on waste management procedures in interior and seaside resorts, as well as cliff-side resorts and town barangays.

6. Finally, the researcher suggests that the program be implemented. 


\section{Acknowledgments}

The researchers express their thanks and gratitude to the important people who, in one way or another, had contributed and extended their help and valuable assistance that made this study possible.

\section{REFERENCES}

Atienza, Vella. (2011). Review of the Waste Management System in the Philippines: Initiatives to Promote Waste Segregation and Recycling through Good Governance. Retrieved on October 13 , 2014, at http://www.ide.go.jp/Japanese/Publish/Download/Report/2010/pdf/2010_4 31_05.pdf

Bernardo EC. (2008, Oct). Solid-Waste Management Practices of Households in Manila, Philippines. Ann N Y Acad Sci.; 1140:420-4. doi:10.1196/annals.1454.016.

Bennagen ME., Nepomuceno G., Covar R. (2002). Solid Waste Segregation and Recycling in Metro Manila: Household Attitudes and Behavior. Retrieved on October 14, 2014, at http://idlbnc.idrc.ca/dspace/bitstream/10625/32393/3/118095.pdf

Billalobos MT. (2010). Assessing the Solid Waste Management Practices in Bacolod City, Philippines. Retrieved on October 13, 2014 at http://arsa1996.org/pictures/pdf/ARSA_IV_PRCDGS_VOL2/ANALYSIS\%2 00F\%20POLICIES\%20RELATED\%20T0\%20AGRICULTURE,\%20NATU RAL\%20RESOURCES\%20MANAGEMENT\%20AND\%20RURAL\%20DE VELOPMENT/4.\%20BALLADOS_37-44.pdf

Ecological Solid Waste Management Act of 2000 (R.A. 9003). The Philippines. Retrieved on October 12 , 2014 at http://www.emb.gov.ph/laws/solid\%20waste\%20management/ra9003.pdf

Pongracz, Eva, "Re-defining the concepts of waste and waste management Evolving the Theory of Waste Management", Department of Process and Environmental Engineering, University of Oulu http: // Herkules. Oulu. fi/isBn9514268210 / ISBN 9514268210.pdf.

Reyes PB., \& Furto MV. (2013). Greening of the Solid Waste Management in Batangas City. Journal of Energy Technologies and Policy.: 3(11), 187194.

U.S. Environmental Protection Agency (EPA). Solid Waste Management: A Local Challenge with Global Impacts, retrieved on October 14, 2014 at http://www.epa.gov/osw/nonhaz/municipal/pubs/ghg/f02026.pdf

U.S. Environmental Protection Agency (EPA). Non-Hazardous Waste Management Hierarchy. Retrieved on October 13, 2014 at http://www.epa.gov/solidwaste/nonhaz/municipal/hierarchy.htm

Pongracz, Eva, "Re-defining the concepts of waste and waste management Evolving the Theory of Waste Management", Department of Process Environmental Engineering, University of Oulu http: // herkules. and fi/isBn9514268210 / isbn 9514268210.pdf.

oulu. 